\title{
PELATIHAN PEMBUATAN PRODUK BERBAHAN DASAR SUSU SAPI DI DESA BALUNG LOR JEMBER
}

\author{
M. Abdul Wahid*1, Mustofa Hilmi*2, Anis Usfah Prastujati"3, IGNB. Catrawedarma ${ }^{\# 4}$, Zulis

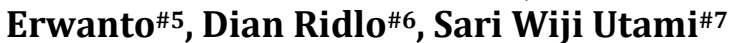

1,4,6Program Studi Teknik Mesin Politeknik Negeri Banyuwangi

5Program Studi Teknik Sipil, Politeknik Negeri Banyuwangi

2,3,7Program Studi Teknologi Pengolahan Hasil Ternak Politeknik Negeri Banyuwangi

Jl. Raya Jember Km. 13, Labanasem, Kabat, Banyuwangi

mustofahilmi@poliwangi.ac.id

\begin{abstract}
ABSTRAK
Balung Lor merupakan desa di Kecamatan Balung Kabupaten Jember mengalami permasalahan dalam penanganan susu sapi. Penanganan yang dilakukan selama ini belum ada sehingga berdampak pada menurunnya kualitas susu sapi menyebabkan penurunan ekonomi dan mengalami kerugian. Fermentasi merupakan solusi dalam penanganan susu sapi menjadi bernilai jual dengan membuat produk baru yaitu yoghurt. Yogurt dibuat dengan proses fermentasi antara susu segar dan bakteri asam laktat (BAL) yang dapat meningkatkan kandungan gizi dan dapat digunakan sebagai memacu pertumbuhan karena meningkatkan pencernaan dan penyerapan zat gizi, mengurangi atau membunuh bakteri jahat dalam saluran pencernaan, menormalkan kerja usus besar (mengatasi konstipasi dan diare), memiliki efek anti kanker, mengatasi masalah lactose intolerance, berperan dalam detoksifikasi dan mengatasi stres, serta mengontrol kadar kolesterol dalam darah dan tekanan darah. Berdasarkan hasil sosialisasi dan pelatihan pengolahan susu sapi menjadi yogurt. Kegiatan ini bertujuan bertujuan membantu memecahkan permasalahan yang dihadapi oleh peternak untuk meningkatkan ekonomi dengan mengaplikasikan teknologi fermentasi yogurt berbahan dasar susu sapi sebagai wujud ketahanan pangan nasional khususnya kelompok Ternak Mandiri Sejahtera di Desa Balung Lor Kecamatan Balung Kabupaten Jember.kegiatan ini dilakukan dengan dua tahapan yaitu sosialisasi dan pelatihan demontrasi pembuatan yoghurt. Hasil kegiatan ini menunjukan respon peserta cukup baik dan kegiatan pelatihan pengolahan susu sapi menjadi yogurt merupakan informasi baru bagi peserta (peternak). Penerapan keterampilan pembuatan produk yogurt juga mungkin dilakukan oleh para peserta karena alat dan bahan yang digunakan relatif mudah ditemukan dilingkungan tempat tinggal mereka. Sehingga pengolahan susu sapi menjadi yogurt berpotensi menjadi salah satu alternatif yang dapat dijadikan sebagai usaha keluarga.
\end{abstract}

Keywords - Fermentasi, Sapi, Susu, Yoghurt

\section{PENDAHULUAN}

Balung Lor merupakan desa di Kecamatan Balung Kabupaten Jember propinsi Jawa Timur. Balung Lor yang juga merupakan ibu kota kecamatan Balung terletak di sebelah selatan Kabupaten Jember, sekitar $24 \mathrm{~km}$ dari Kota Jember. Didesa ini terdapat kelompok ternak sapi perah yaitu kelompok Kelompok Ternak Mandiri Sejahtera. Produksi susu sapi dikelompok ini rata-rata perhari berkisar 7-9 liter/ekor. Potensi produksi susu sapi didesa ini cukup besar tetapi seluruh peternak hanya menjual susu sapi dalam keadaan segar. Disisi lain kelompok ternak juga mengeluhkan harga susu yang rendah bekisar Rp.6.000/liter, hanya bisa menutupi biaya produksi dan sedikit keuntungan. Ini terlihat dari kehidupan social ekonomi peternak yang masih dalam kategori sangat sederhana. 
Berdasarkan beberapa permasalahan dan teknologi yang diuraikan diatas, maka melalui program diseminasi produk teknologi ini mencoba membantu mencarikan solusi terhadap permasalahan yang dialami oleh kelompok ternak Mandiri Sejahtera dengan mentransfer tekhnologi pengolahan susu sapi menjadi yoghurt (susu fermentasi) yang kaya akan rasa, manfaat dan juga daya simpan yang lebih lama (Clark, Costello et al. 2009, Fuquay, Fox et al. 2011). Yogurt dibuat dengan proses fermentasi antara susu segar dan bakteri asam laktat (BAL) (Fuquay, Fox et al. 2011). Menurut White, Kilara et al. (2008) bahwa keuntungan pengolahan air susu sapi menjadi yoghurt adalah dapat meningkatkan kandungan gizi. Menurut Yildiz (2016) bahwa kandungan gizi yoghurt relatif lebih tinggi dibandingkan dengan air susu segar yang merupakan bahan baku untuk pembuatan yoghurt, karena yoghurt memiliki padatan lebih tinggi. Yoghurt juga dapat digunakan memacu pertumbuhan karena meningkatkan pencernaan dan penyerapan zat gizi, mengurangi atau membunuh bakteri pantogen dalam saluran pencernaan, menormalkan kerja usus besar (mengatasi konstipasi dan diare), memiliki efek anti kanker, mengatasi masalah lactose intolerance, berperan dalam detoksifikasi dan mengatasi stres, serta mengontrol kadar kolesterol dalam darah dan tekanan darah (White, Kilara et al. 2008, Clark, Costello et al. 2009, Fuquay, Fox et al. 2011, Yildiz 2016).

\section{TARGET DAN LUARAN}

Sosialisasi dan pelatihan pengolahan produk berbahan susu sapi (yoghurt)ke masyarakat bertujuan membantu memecahkan permasalahan yang dihadapi oleh peternak untuk meningkatkan ekonomi dengan mengaplikasikan teknologi fermentasi yogurt berbahan dasar susu sapi sebagai wujud ketahanan pangan nasional khususnya kelompok Ternak Mandiri Sejahtera di Desa Balung Lor Kecamatan Balung Kabupaten Jember.

Sasaran program ini adalah para peternak atau kelompok ternak sapi perah yang ada di Desa Balung Lor Kecamatan Balung Kabupaten Jember propinsi Jawa Timur.
Target luaran dalam program diseminasi produk teknologi ke kelompok ternak Ternak Mandiri Sejahtera adalah berupa aplikasi teknologi fermentasi susu yogurt di Desa Balung Lor Kecamatan Balung Kabupaten Jember propinsi Jawa Timur.

TABEL I. RENCANA TARGET CAPAIAN LUARAN

\begin{tabular}{|c|l|l|}
\hline No & \multicolumn{1}{|c|}{ Jenis Luaran } & \multicolumn{1}{|c|}{$\begin{array}{c}\text { Indikator } \\
\text { Capaian }\end{array}$} \\
\hline 1 & $\begin{array}{l}\text { Publikasi ilmiah di } \\
\text { jurnal/prosiding }\end{array}$ & Submitted \\
\hline 2 & $\begin{array}{l}\text { Publikasi pada media massa } \\
\text { (cetak/elektronik) }\end{array}$ & Sudah terbit \\
\hline 3 & $\begin{array}{l}\text { Peningkatan omzet pada } \\
\text { mitra yang bergerak dalam } \\
\text { bidang ekonomi }\end{array}$ & Tidak ada \\
\hline 4 & $\begin{array}{l}\text { Peningkatan kuantitas dan } \\
\text { kualitas produk }\end{array}$ & Ada \\
\hline 5 & $\begin{array}{l}\text { Peningkatan pemahaman dan } \\
\text { ketrampilan masyarakat }\end{array}$ & ada \\
\hline 6 & $\begin{array}{l}\text { Peningkatan } \\
\text { ketentraman/kesehatan } \\
\text { masyarakat (mitra } \\
\text { masyarakat umum) }\end{array}$ & ada \\
\hline 7 & $\begin{array}{l}\text { Jasa, model, rekayasa sosial, } \\
\text { sistem, produk/barang }\end{array}$ & Produk \\
\hline 8 & $\begin{array}{l}\text { Hak kekayaan intelektual } \\
\text { (paten, paten sederhana, hak } \\
\text { cipta, merek dagang, rahasia } \\
\text { dagang, desain produk } \\
\text { industri, perlindungan } \\
\text { varietas tanaman, } \\
\text { perlindungan topografi. }\end{array}$ & Tidak ada \\
\hline 9 & Buku Ajar & Tidak ada \\
\hline
\end{tabular}

Sumber : Hasil Analisis, 2017

\section{METODE PELAKSANAAN}

Dalam pelaksanaan program ini, metode pelaksanaan yang digunakan didasari dari permasalahan yang ada pada Kelompok Ternak Mandiri Sejahtera di Desa Balung Lor Kecamatan Balung Kabupaten Jember Propinsi Jawa Timur yaitu mengatasi permasalahan dalam penangan susu sapi dengan aplikasi teknologi fermentasi susu (yogurt) melalui sosialisasi dan pelatihan kepada kelompok Ternak Mandiri Sejahtera mengenai program yang akan dilaksanakan melalui tahapan kegiatan antara lain:

1. Pelatihan berasal dari TIM Desiminasi

Teknologi Politeknik Negeri Banyuwangi, sedangkan peserta adalah kelompok Ternak 
Mandiri Sejahtera di Desa Balung Lor Kecamatan Balung Kabupaten Jember.

2. Melalui sosialisasi dan pelatihan ini diberikan materi bagaimana peningkatan nilai tambah produk susu sapi segar menjadi yoghurt.

3. Bagaimana menghasilkan produk yang berorientasi pasar dengan memperhatikan efisiensi produksi dan pemasaran.

4. Melakukan pelatihan pembuatan yoghurt dari susu sapi segar.

Prosedur Pengolahan Yoghurt Berbahan Dasar Susu Sapi ; Bahan baku yang digunakan dalam pembuatan yoghurt yaitu susu sapi segar dari kelompok ternak Mandiri Sejahtera sedangkan starter bakteri yang digunakan Biokul plan yang didapatkan di Swalayan areal Jember. Adapun tahapan-tahapan kegiatan yang akan dilakukan dalam pembuatan yoghurt adalah sebagai berikut :

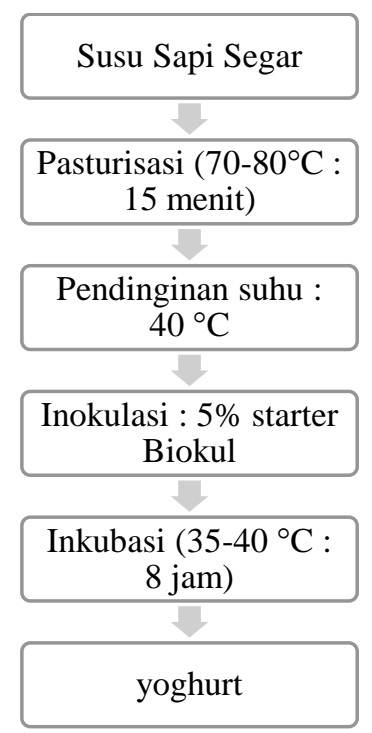

\section{KELAYAKAN PERGURUAN TINGGI}

P3M (Pusat Penelitian Dan Pengabdian Kepada Masyarakat) Politeknik Negeri Banyuwangi telah beberapa kali ikut berperan aktif dalam program pengabdian kepada masyarakat seperti berikut.

1. IbM Kelurahan Sobo dalam Pemberdayaan Ibu-ibu rumah Tangga Non Produktif

2. IbM Desa Purwodadi Kecamatan Gambiran Melalui Rancang Bangun Pembangkit Listrik
Tenaga Matahari (PLTM) Sebagai Upaya Peningkatan Frekuensi Produksi Hasil Panen Tanaman Buah Naga Merah

3. IbM Desa Tulikup Dalam Upaya Meningkatkan Produktivitas Usaha Batu Bata Bali

4. IbM Kelompok Pengguna Air Bersih Desa Pakel Melalui Teknologi Filter Beton Pasir

5. Pemanfaatan Teknologi Tepat Guna Pembuatan Briket Limbah Kotoran Ternak Ruminansia

6. IbM Peningkatan Daya Saing Produk Madu Desa Taman Sari Kabupaten Banyuwangi

7. IbM Pemberdayaan Kelompok Ternak Kambing Etawa Melalui Pelatihan Dan Pendampingan Dalam Produksi Silase Sebagai Pakan Ternak Alternatif Di Desa Wongsorejo

8. Rancang Bangun Mesin Pembelah Juring Bambu Untuk Meningkatkan Produktifitas UMKM Penghasil Tempat Ikan Pindang Desa Blambangan Kecamatan Muncar

9. IbM Mesin Pencetak Pellet Ikan Lele Di Desa Kedungrejo Kecamatan Muncar

10. IbM Puskesmas Kecamatan Licin Melalui Pembuatan Dan Pelatihan Sistem Monitoring Emosional Pasien Berbasis Java

11. IbM Penerapan Teknologi Tepat Guna Mesin Penghalus Kotoran Kambing Untuk Pupuk Organik Tanaman Jeruk

12. IbM Penyuluhan Dan Pelatihan Sistem Tanam Padi 454 Kelompok Tani Sumber Urip Desa Watu Kebo

13. Desiminasi Teknologi Produk Pengering Padi Untuk Ketahanan Pangan Kelompok Tani di Desa Wringin Putih kecamatan Muncar Banyuwangi

14. Desiminasi Produk Teknologi Mesin Pemerah Lendir Biji Kakao di Desa Sumberagung Kecamatan Pesanggaran Banyuwangi

\section{HASIL DAN LUARAN YANG DICAPAI}

Dalam proses pelaksanaan pelatihan fermentasi susu yogurt ini terlebih dahulu dilakukan sosialisasi tentang pentingnya pembuatan teknologi fermentasi yogurt bagi masyarakat dan juga pentingnya hilirisasi teknologi ke masyarakat khususnya pengolahan susu. 
Kegiatan sosialisasi dan pelatihan dilaksanakan pada tanggal 5 November 2017 dengan materi pertama yaitu pengenalan yoghurt yang disampaikan dengan metode ceramah dan materi yang kedua yaitu cara pembuatan yogurt yang dilakukan dengan menggunakan metode demonstrasi. Materi pertama yang disampaikan meliputi pengenalan yogurt dan manfaat bagi kesehatan pencernaan.

Berdasarkan hasil kegiatan diperoleh informasi bahwa peserta kegiatan sebagian besar belum mengenal minuman yogurt dan manfaat yang terkandung dalam minuman tersebut. Meskipun telah diketahui bahwa produk yogurt komersil sudah banyak beredar dipasaran. Sebagian peserta menuturkan sudah pernah mengkonsumsi yogurt komersil tersebut tapi tidak mengetahui bagaimana proses pembuatannya dan manfaat yang terkandung dalam minuman tersebut. Sedangkan untuk pengolahan susu menjadi minuman fermentasi yogurt belum diketahui oleh para peserta pelatihan dan menjadi informasi baru bagi mereka. Selama proses diskusi sesi pertama, terlihat ibu-ibu peserta antusias mengajukan pertanyaan mengenai materi yang telah disampaikan.

Penyampaian materi kedua meliputi alat dan bahan yang digunakan serta tahapan dalam proses pembuatan yogurt. Proses pembuatan yogurt menggunakan bahan susu sapi, sehingga memungkinkan bagi peserta untuk mempraktekan informasi yang telah diperoleh dirumah masing-masing. Begitu juga dengan peralatan yang digunakan selama proses pembuatan merupakan peralatan yang pastinya telah dimiliki oleh peserta dirumah masingmasing. Sehingga penerapan pembuatan yogurt akan semakin mudah dilakukan. Berdasarkan sesi diskusi, terlihat para peserta antusias dalam menerima informasi yang telah diberikan dan antusias akan mencoba sendiri pembuatan yogurt tersebut. Setelah penyampaian proses pembuatan yogurt, materi selanjutnya yaitu demonstrasi pembuatan minuman olahan berbahan dasar susu dijadikan yogurt.

Adapun tahapan pembuatan yoghurt adalah sbb :
- Susu segar dipanaskan dengan suhu $70^{\circ} \mathrm{C}$ $80^{\circ} \mathrm{C}$ (Gunakan thermometer)

- Setelah itu matikan api kompor dan turunkan suhu sampai $40^{\circ} \mathrm{C}$ dengan mengaduk-aduknya secara perlahan-lahan

- Masukkan 5\% stater (Biokul) dan aduk sampai rata

- Masukkan dalam stoples dan tutup

- Letakkan didalam almari (supaya panas dari lemari pendingin bisa mempercepat proses fermentasi)

- Simpan selama 8 jam

- Yoghurt siap digunakan

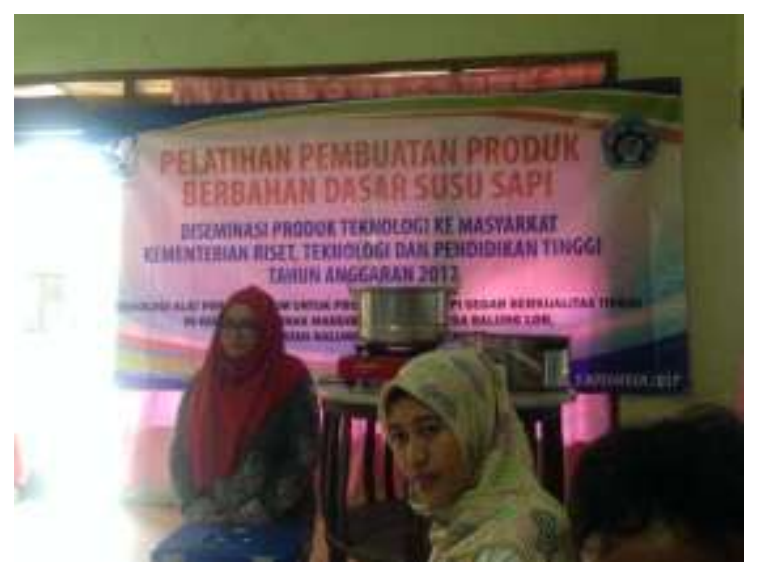

Gambar 1. Pelatihan Pembuatan Produk Berbahan Dasar Susu Sapi (Yoghurt)

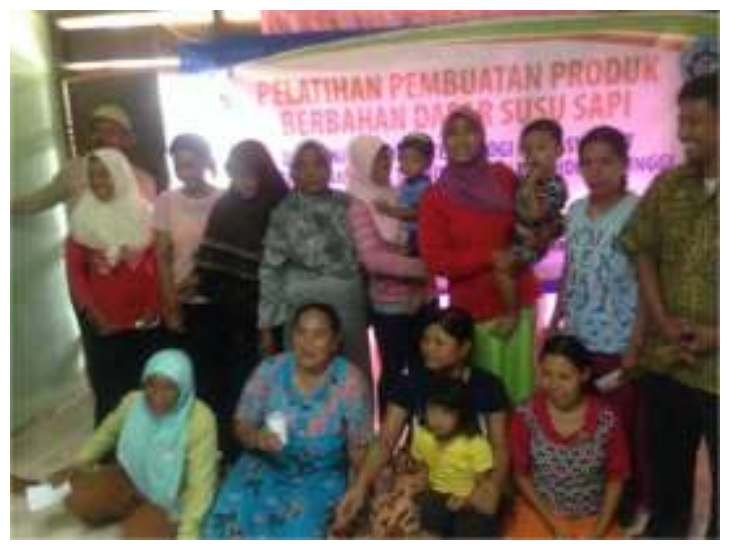

Gambar 2. Peserta Pelatihan Produk Berbahan Dasar Susu Sapi (Yoghurt) 


\section{KESIMPULAN DAN SARAN}

1. Berdasarkan hasil sosialisasi dan pelatihan dilakukan dalam dua tahapan penyampaian materi dan tahapan demontrasi pembuatan produk berbahan dasar susu dijadikan yoghurt

2. Respon peserta pelatihan terhadap kegitan yang dilakukan cukup baik terlihat dari antusiasme peserta selama proses kegiatan berlangsung

3. Hasil sosialisasi dan pelatihan dapat menjadi informasi baru bagi peternak dalam pengolahan susu sapi (yoghurt) dan dapat menjadi salah satu alternatif usaha keluarga.

\section{UCAPAN TERIMA KASIH}

Kegiatan ini terselenggara atas peran serta dari 3 lembaga yaitu Direktorat Riset dan Pengabdian Masyarakat (DRPM), Kemenristekdikti, Politeknik Negeri Banyuwangi (Poliwangi), dan Kelompok Ternak Mandiri Sejahtera di Desa Balung Lor Kecamatan Balung Kabupaten Jember Propinsi Jawa Timur. DRPM selaku pendukung dana, Politeknik Negeri Banyuwangi selaku pelaksana program desiminasi teknologi dan kelompok tani selaku mitra dalam program ini. Oleh karena itu, dalam kesempatan ini disampaikan ucapan terimakasih yang sebesar-besarnya atas bantuan dan dukungan untuk terselenggaranya kegiatan desiminasi teknologi ini.

\section{DAFTAR PUSTAKA}

Bakri, A., Hariono, B., \& Utami, M. M. D. (2018, January). Inactivation of Bacteria $S$. aureus ATCC 25923 and S. Thyphimurium ATCC 14 028 Influence of UV-HPEF. In Journal of Physics: Conference Series (Vol. 953, No. 1, p. 012122). IOP Publishing.

Clark, S., M. Costello, M. Drake dan F. Bodyfelt (2009). The sensory evaluation of dairy products, Springer.

Fuquay, J. W., P. F. Fox dan P. L. McSweeney (2011). Encyclopedia of dairy sciences, Academic Press.
White, C. H., A. Kilara dan Y. Hui (2008) Manufacturing yogurt and fermented milks, John Wiley \& Sons.

Yildiz, F. (2016). Development and manufacture of yogurt and other functional dairy products, CRC Press. 